\title{
In Memoriam - Dr. Leon M. Payawan Jr.
}

\author{
Ken Aldren S. Usman', Yasmin D.G. Edañol ${ }^{2}$, Marlon T. Conato ${ }^{3 *}$ \\ ${ }^{1}$ Institute for Frontier Materials, Deakin University, Geelong, VIC 3216, Australia \\ ${ }^{2}$ Natural Sciences Research Institute, University of the Philippines, Diliman, Quezon City, 1101, Philippines \\ ${ }^{3}$ Institute of Chemistry, National Science Complex, University of the Philippines, Diliman, Quezon City, 1101, \\ Philippines
}

*Author to whom correspondence should be addressed; email: mtconato@up.edu.ph

\begin{abstract}
On September 25, 2020, the Philippine chemistry society lost one of its most eminent members. Herein we reflect on the life and work of Dr. Leon M. Payawan Jr., referred to as Leon by his close friends and colleagues. We highlight some of his contributions that left a huge impact, not only to his students and cohorts, but also to the Philippine research community in general, both locally and internationally.
\end{abstract}

Keywords: Leon Payawan Jr; inorganic chemistry, nanomaterials; photocatalysts; Philippine chemistry

\section{INTRODUCTION}

Dr. Leon M. Payawan Jr., Leon as called by his close friends, peacefully passed away in his residence inside UP Diliman campus in Quezon City, on September 25, 2020 at the age of 58. Dr. Payawan was a Professor at the Institute of Chemistry, University of the Philippines - Diliman (IC-UPD). He was the President of the Kapisanang Kimika ng Pilipinas (KKP) and the Vice President of the Philippine Federation of Chemistry Societies (PFCS) at the time of his passing. His career was devoted in promoting awareness and improving the country's level of inorganic and materials chemistry research towards global competitiveness through headship of essential projects, mentorship of young researchers, and leadership in national organizations.

\section{HUMBLE BEGINNINGS}

Born in Calamba, Laguna on April 24, 1962, Dr. Payawan finished his elementary and high school education at the UP Elementary School (1972 to 1975) and the UP Integrated school (1975 to 1979), respectively. He then obtained his Bachelor of Science degree from the Department of Chemistry (now Institute of Chemistry or IC), UP-Diliman (UPD) in 1984. His science career started as a research assistant at the Natural Sciences Research Institute (NSRI) (1984-1986) before working as an analyst at the Philippine Institute for Pure and Applied Chemistry (PIPAC) (1986- 
1989). He returned to IC-UPD to serve as an Instructor in 1989 and became a student fellow for the UP-ADMU-DLSU consortium (1991-1994). As a member of the IC-UPD junior faculty, Leon enjoyed the privilege of being enrolled in the graduate program of the institute where he received grants from several scholarship programs including the Australian International Development InCountry Training Program (October 1993 - June 1994) and the Department of Science and Technology -Engineering and Science, Education Project (DOST-ESEP) Sandwich Program (January 1996 - September 1996 and October 1996 - January 1997). These programs provided an opportunity for him to conduct research in international facilities such as the Intelligent Polymer Research Laboratory, at the University of Wollongong (Australia) and Environmental Technology Department at the University of Karlsruhe (Germany), and had the privilege of being mentored by distinguished professors, Dr. Gordon G. Wallace (University of Wollongong) and Dr. André M. Braun (University of Karlsruhe).

After finishing his Ph.D. in Chemistry in 1999, he was appointed as an Assistant Professor and performed several government- and privately-funded research projects, either as a project leader or as a project consultant. Among these works include projects funded by the NSRI, DOST, Department of Agriculture, and Energy Development Corporation (EDC), most of which focuses on the use of nano-sized and framework-based materials in heterogeneous catalysis for sustainable energy and environmental applications. For further professional advancement, Dr. Payawan worked as a postdoctoral research scientist in several occasions including those funded by the University of Toronto under the mentorship of Professor Ma. Cynthia Goh (April 2002 to September 2002 and February 2003 to August 2003) and the Department of Agriculture - Bureau of Agricultural Research (DA-BAR) (January 2007 to December 2007).

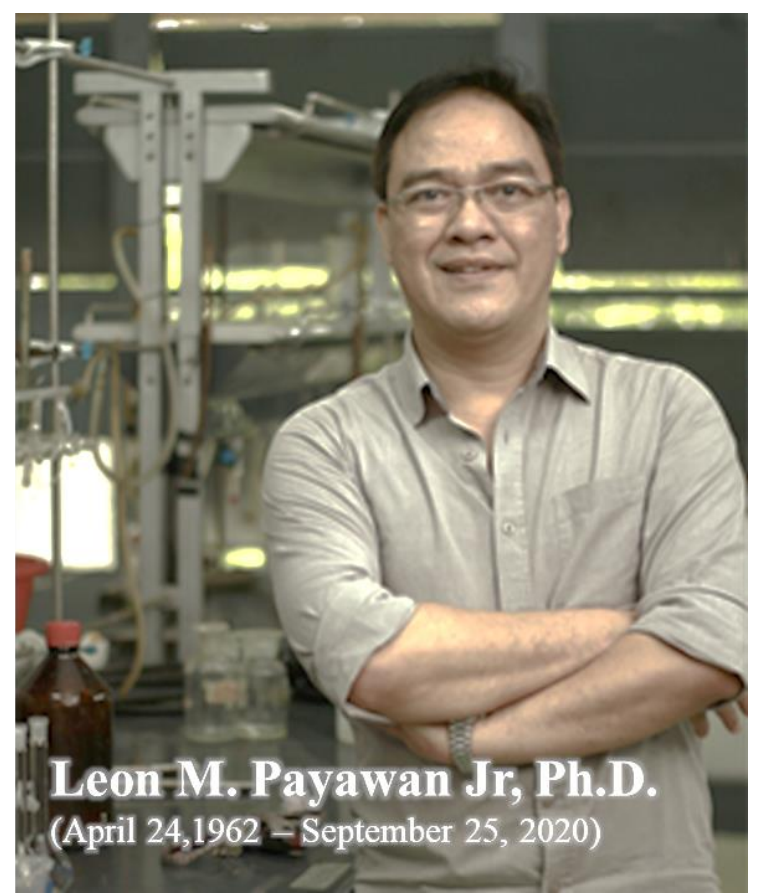

Figure 1. A photograph of the late Dr. Payawan (1962-2020) taken at the old Institute of Chemistry Building, Pavilion 1, Palma Hall, University of the Philippines in Diliman, circa 2010.

\section{A PASSIONATE RESEARCHER, MENTOR AND TEACHER}

Dr. Payawan has devoted majority of his time in managing research projects and mentoring young chemistry and materials science researchers in UP Diliman. An impressive scientific productivity driven by an outstanding talent earned him an Associate Professorship and Full Professorship positions in 2005 and 2014, respectively. He also established himself as one of the most highly 
cited academic researchers of IC-UPD (with more than 870 article citations as per Google Scholar record as of September 2020), as he has played major roles in shaping the key research strengths of the institute through multidisciplinary and collaborative research in the areas of inorganic chemistry and materials science. As an example, his research along with his colleague Dr. Stefan $\mathrm{H}$. Bossmann on co-immobilized titanium dioxide $\left(\mathrm{TiO}_{2}\right)$ and ruthenium (II)-tris(bipyridine) onto zeolite Y (Bossmann et al., 1998; Bossmann et al., Bossmann et al., 2003) are highly cited articles in the field of heterogeneous catalysis, which helped realize diverse novel applications. Among these applications include the use of the material as catalyst for the degradation of organic pollutants as well as an efficient light harvesting material for potential solar cell devices. Due to his consistent annual research contributions to the university, Dr. Payawan was a perennial awardee of the One UP Professorial Chair and the UP Centennial Professorial Chair and Faculty Grant. These awards were only given to selected university faculty with exceptional research output. In addition, he was posthumously conferred the rank of UP Scientist I for the 2019-2021 cycle. The award is given by the UP System to the most productive faculty members and researchers within its constituent units.

For around two decades in UP, he mentored more than 10 graduate students and 39 undergraduate students as thesis adviser. He also served as a member of the thesis committee on 12 masteral and 5 doctoral candidates either as a reader or as an examiner. Through his supervision, his students have addressed some of the major challenges in materials science research, specifically in understanding the properties of various materials such as the metal oxides $\mathrm{TiO}_{2}$ (Usman et al., 2017; Buenviaje et al., 2020; Panghulan et al., 2020), $\mathrm{Fe}_{3} \mathrm{O}_{4}$ (Gorospe et al., 2019), $\mathrm{ZnO}$ (Magdaluyo et al., 2007), and $\mathrm{SiO}_{2}$ (Edañol et al., 2018), colloidal silver (Usman et al., 2015; Usman et al., 2014), zeolites (Trinidad et al., 2016; Trinidad et al., 2017), metal-organic frameworks (Usman et al., 2018; Usman et al., 2020), and layered double hydroxides (Edañol et al., 2020) along with their respective development towards a wide array of applications such as energy conversion, sensing, bioremediation, and drug delivery.

As a teacher, he is best known among his students as a strict and tough enforcer who demanded consistent excellence in all aspects of work, as well as one who has a wonderful sense of humor. In his more than 30 years of experience in the academe, he helped several generations of students appreciate inorganic chemistry and materials science as an essential and continuously emerging scientific field that would be critical in the development of a society.

\section{ELEVATING PHILIPPINE CHEMISTRY TOWARDS GLOBAL COMPETITIVENESS}

Dr. Payawan also took several administrative roles in both university and national organizations. He was part of KKP for almost 20 years where he served as President of KKP's Division of Inorganic Chemistry and Allied Fields (KKP-DICAF) before being elected as member of its National Board of Directors early in this past decade. He was also elected as KKP Vice-President in 2016 before being elected as President in 2017. On that same year, Dr. Payawan also took the position of Vice-President for PFCS. He also served as the Deputy Director for Research and Extension of IC-UPD and as member of NSRI Executive Council from 2014 to 2017. His expertise was also recognized by the Department of Trade and Industry - Bureau of Product Standards (DTI-BPS) where he was appointed a member of its Technical Committee since 2019. Through his posts in these organizations, he actively explored avenues to develop and highlight the skill of young student researchers and faculty. His outreach activities include organizing public lectures/seminars, involvement as judge/panel in competitions, and enthusiastically participating in workshops for undergraduate and graduate students about career development and even 
academic writing. He has been a reviewer in several occasions to local journals such as Kimika and the Philippine Journal of Science as well as in several international ISI-indexed publications.

An important highlight of Dr. Payawan's service to the chemistry community in the country is his spearheading of international and local conferences including the 10th Eurasia Conference on Chemical Sciences 2008 (PICC, Manila, Philippines) and more recently, the $34^{\text {th }}$ Philippine Chemistry Congress 2019 (Cebu City, Philippines). Both conferences not only featured locallybased experts but also Filipino scientists from prominent foreign institutions, which is in accord with Dr. Payawan's vision of recognizing Filipino scientists in the international stage.

\section{LEON AS A PERSON OUTSIDE THE ACADEMIA}

Even with his busy schedule, Dr. Payawan maintained balance in his social and personal life. For relaxation, Leon liked to watch movies and have videoke sessions with his research group and friends. Moreover, he valued personal interactions and would occasionally treat you for a merienda or dinner. These light moments would also be an opportunity for him to share his experiences to his students and advisees and incidentally would boost research productivity. Leon also regarded guests and visiting professors special, even willing to spend his personal money in order to keep them more comfortable.

Dr. Payawan was also known for his extreme affection for both cats and dogs, on which prior to his death, he was taking care of five dogs and seven cats in his house.

Leon will be remembered by everyone for his radiant smile and his colorful greetings to everyone he meets including the staff, students, and personal acquaintances. For those who personally knew Dr. Payawan, he will be remembered as one of the most generous and down-to-earth professors in UP.

\section{A CONTINUING LEGACY}

The Philippine chemistry community may have lost Dr. Payawan too soon, but his impact rests in the collaborations he forged and the students he mentored. Till his death, his former students, both local and international, continued to collaborate with him even after years of leaving UP. Most of whom are already renowned scientists and professionals, or are currently pursuing advanced degrees in various institutions. Notable example of his former students' works include projects that provide opportunities to new generation of researchers in the country by training and advocacy programs aimed towards promoting science and technology ( $S \& T$ ). As of this writing, IC-UPD and the UPD College of Science are crafting a research support or grant in honor of Leon to provide promising students pursue their research in the field of materials chemistry. Through these efforts, it is assured that Dr. Payawan's contributions to the country's S\&T research, particularly in the field of inorganic nanomaterials will continue to live on.

\section{REFERENCES}

Buenviaje SC Jr, Usman KAS, Edañol YDG, Maylem GP, Payawan LM Jr. One-pot photochemical synthesis of solution-stable $\mathrm{TiO}_{2}$-polypyrrole nanocomposite for the photodegradation of methyl orange. Key Engineering Materials. 2020 July; 853:217-22. https://doi.org/10.4028/www.scientific.net/kem.853.217 
Bossmann SH, Oliveros E, Göb S, Siegwart S, Dahlen EP, Payawan L, Straub M, Wörner M, Braun AM. New evidence against hydroxyl radicals as reactive intermediates in the thermal and photochemically enhanced fenton reactions. J Phys Chem A. 1998 April; 102(28):5542-5550. https://doi.org/10.1021/jp980129j

Bossmann SH, Turro C, Schnabel C, Pokhrel MR, Payawan LM, Baumeister B, Wörner M. $\mathrm{Ru}(\mathrm{bpy}) 3^{2+} / \mathrm{TiO}_{2}$-codoped zeolites: synthesis, characterization, and the role of $\mathrm{TiO} 2$ in electron transfer photocatalysis. J Phys Chem B. 2001 May; 105(23):5374-5382. https://doi.org/10.1021/jp002480m

Bossmann SH, Jockusch S, Schwarz P, Baumeister B, Göb S, Schnabel C, Payawan L Jr, Pokhrel MR, Wörner M, Braun AM, Turro NJ. Ruthenium(ii)-tris-bipyridine/titanium dioxide codoped zeolite Y photocatalysts: II. Photocatalyzed degradation of the model pollutant 2,4-xylidine, evidence for percolation behavior. Photochem Photobiol Sci. 2003 March; 2:477-486. https://doi.org/10.1039/B212377K

Edañol YD, Usman KAS, Buenviaje SC Jr, Mantua ME, Payawan LM Jr, Utilizing silica from rice hull for the hydrothermal synthesis of zeolite Y. KIMIKA 2018 June, 29(1):17-21. https://doi.org/10.26534/kimika.v29i1.17-21

Edañol YDG, Poblador JAO, Talusan TJE, Payawan LM. Co-precipitation synthesis of Mg-Al$\mathrm{CO}_{3}$ layered double hydroxides and its adsorption kinetics with phosphate $(\mathrm{V})$ ions. Materials Today: Proceedings. 2020 June; In Press. https://doi.org/10.1016/j.matpr.2020.05.059

Gorospe AEB, Buenviaje SC, Edañol YDG, Cervera RBM, Payawan LM Jr. One-step coprecipitation synthesis of water-stable poly(ethylene glycol)-coated magnetite nanoparticles. J Phys Conf Ser. 2019 November; 1191: 012059. https://10.1088/1742-6596/1191/1/012059

Magdaluyo ER Jr, Arellano IHJ, Tapia AKG, Samargo RV, Payawan LM, Photoluminescence and fractal properties of diverse carbothermal zinc oxide nanostructures. Adv Mater Res. 2007, 31:9294. https://doi.org/10.4028/www.scientific.net/AMR.31.92

Panghulan GR, Vasquez MR Jr, Edañol YD, Chanlek N, Payawan LM Jr. Synthesis of TiN/Ndoped $\mathrm{TiO}_{2}$ composite films as visible light active photocatalyst. J Vac Sci \& Technol B. 2020 September; 38:062203. https://doi.org/10.1116/6.0000304

Trinidad LJPL, Usman KAS, Payawan LM Jr. Singlet oxygen production of photocatalytic Ir (III) complex impregnated unto zeolite $\mathrm{NaY}$ supercages. Applied Mechanics and Materials. 2017 February; 863:89-92. https://doi.org/10.4028/www.scientific.net/AMM.863.89

Trinidad LJPL, Arguilla MQ, Usman KAS, Payawan LM Jr. Ship-in-a-bottle synthesis of fluorescent iridium (III) complex ion unto zeolite Y supercages. Key Eng Mater, 2016 September; 707:135-138. https://doi.org/10.4028/www.scientific.net/KEM.707.135

Usman KAS, Trinidad LJPL, Espenilla MBL, Payawan LM Jr. Investigating the $\mathrm{pH}$ dependence of ultraviolet radiation induced synthesis of $\mathrm{TiO}_{2} /$ poly(acrylic acid) nanocomposites. Applied $\begin{array}{llll}\text { Mechanics and } & \text { Materials. } & 2017 & \text { February; }\end{array}$ https://doi.org/10.4028/www.scientific.net/AMM.863.78

Usman KAS, Trinidad LJPL, Payawan LM. UV-irradiation induced synthesis of fluorescent poly (acrylic acid) stabilized silver clusters. MATEC Web of Conferences. 2015 October; 27: 01007. https://doi.org/10.1051/matecconf/20152701007 
Usman KAS, Rosales AV, Payawan LM. Fluorescent property of gamma-irradiated silver/ poly(acrylic acid) nanocomposites. KIMIKA. 2014 October, 25(2):1-10. https://doi.org/10.26534/kimika.v25i2.1-10

Usman KAS, Buenviaje SC Jr, Edañol YDG, Conato MT, Payawan LM Jr. Facile fabrication of a potential slow-release fertilizer based on oxalate-phosphate-amine metal-organic frameworks (OPA-MOFs). Materials Science Forum. 2018 October; 936:14-19. https://doi.org/10.4028/www.scientific.net/MSF.936.14

Usman KAS, Maina JW, Seyedin S, Conato MT, Payawan LM, Dumée LF, Razal JM. Downsizing metal-organic frameworks by bottom-up and top-down methods. NPG Asia Materials. 2020 September; 12(1):58. https://doi.org/10.1038/s41427-020-00240-5 